\title{
Mycology of Hand-dug Shallow Water Wells in Awka Metropolis, Anambra State, Nigeria
}

\author{
Onuorah Samuel*, Elesia Rosemary, Odibo Frederick
}

Department of Applied Microbiology and Brewing, Nnamdi Azikiwe University, Nigeria

Copyright $\bigcirc 2016$ by authors, all rights reserved. Authors agree that this article remains permanently open access under the terms of the Creative Commons Attribution License 4.0 International License

\begin{abstract}
Samples collected from hand-dug shallow water wells in Awka metropolis during the dry and wet seasons were subjected to mycological analysis to determine their safety for use. The fungal counts during the dry and wet seasons were $3.5 \times 10^{3} \mathrm{cfu} / \mathrm{ml}-8.2 \times 10^{3} \mathrm{cfu} / \mathrm{ml}$ and $5.1 \times 10^{3} \mathrm{cfu} / \mathrm{ml}-10.6 \times 10^{3} \mathrm{cfu} / \mathrm{ml}$ respectively. The fungi isolated during the dry and wet seasons respectively were Candida albicans (42.0\% and 44.8\%), Cryptococcus neoformans $(9.6 \%$ and 10.2\%), Rhodotorula Harrison (11.5\% and $12.6 \%)$, Microsporium canis (0.0\% and $0.2 \%)$, Penicillium chrysogenum (28.0\% and 29.3\%), Alternaria alternata (0.0\% and $0.3 \%)$, Mucor mucedo (8.9\% and $9.2 \%)$ and Sepedonium chrysospermum (0.0\% and $0.2 \%)$. Candida albicans, Cryptococcus neoformans, Rhodotorula harrison, Penicillium chrysogenum and Mucor mucedo were isolated from $46.7 \%, 6.7 \%, 20.0 \%, 26.7 \%$ and $6.7 \%$ of the samples respectively during the dry season while $60.0 \%, 20.0 \%$, $26.7 \%, 6.7 \%, 40.0 \%, 13.3 \%, 20.0 \%$ and $6.7 \%$ of the samples respectively had Candida albicans, Cryptococcus neoformans, Rhodotorula harrison, Microsporium canis, Penicillium chrysogenum, Alternaria alternata, Mucor mucedo and Sepedonium chrysospermum. These fungi are human pathogens which are known to cause diseases of animals and humans which if untreated may lead to fatal consequences, therefore adequate treatment of the water will safeguard the health of the users.
\end{abstract}

Keywords Hand-dug, Shallow Water, Wells, Fungi, Awka, Metropolis

\section{Introduction}

Ground water is an increasingly important resource all over the world. It is the subsurface water that occurs beneath the water table in soils and geological formations that are fully saturated. It supports drinking water supplies, livestock needs, irrigation, industrial and many commercial activities. Ground water is generally less susceptible to contamination and pollution when compared to surface water bodies [1].
Ground water can be contaminated by naturally occurring sources. Soil and geological formation containing high levels of heavy metals can leach those metals into ground water. This can be aggravated by over pumping wells, particularly for agriculture [2]. Pollution caused by fertilizers and pesticides used in agriculture, is a great threat to fresh ground water ecosystems. The quality of ground water is a function of natural processes as well as anthropogenic activities [3].

The original source of any drinking water is rich in aquatic microbes, some of which could be dangerous if they enter the human body. Water related health problems are a growing human tragedy and some 1.1 billion people who rely on unsafe drinking water are in sub-saharan Africa (58\%) with a corresponding low sanitation coverage rate $(36 \%)$ which leads to many deaths especially among children through diarrhea among other water-related diseases [4].

Drinking water supplies have a long history of being infected by a wide spectrum of microbes, therefore, the primary goal of water quality management from health perspective is to ensure that consumers are not exposed to pathogens that cause diseases. Protection of water resources and treatment of water supplies have greatly reduced the incidence of these diseases in developing countries therefore testing the sources of water is necessary, especially when there is no water treatment. This is useful as a result of the failure of treatment processes or as a part of an investigation of a serious water borne disease outbreak [5].

The majority of the populations in developing countries is not adequately supplied with potable water and is thus compelled to use water from sources like shallow wells that render the water unsafe for domestic and drinking purposes due to high possibilities of contamination [6]. In Nigeria, only a minority of residents draws their water from piped municipal supplies while less than half the populations rely on piped water, with the remaining drawing from boreholes, rivers and water vendors. Risks of water borne diseases are therefore a major public health concern in Nigeria.

Fungi are a significant cause of water pollution due to their ability to survive after filtration [7,8]. Many aquatic fungi, including important human pathogens are able to grow on land and in water. The presence of fungi in water has often 
been overlooked, but they may cause serious health problems in humans, therefore in this work, the mycology of hand-dug shallow water wells in Awka metropolis, Nigeria was studied during the dry and wet seasons.

\section{Materials and Methods}

\subsection{Sample Collection}

Water samples were collected from fifteen hand-dug shallow wells in different locations in Awka metropolis, Nigeria. The wells were located in Okpuno Awka, Ifite Awka, Okperi Awka, Umuogbo Awka, Ogbengwu Awka, Umuokpu Awka, Umunagu Awka, Sugarline Amansea, Ngo Amansea, Omeluora Close Amansea, Okoye Close Amansea, Orji Avenue Amansea, Akurulo Avenue Amansea, Obi Avenue Amansea and Kenneth Close Amansea. The samples were collected in $100 \mathrm{ml}$ sterile glass containers with screw caps and legibly labeled. They were transported to the microbiology laboratory of Nnamdi Azikiwe University Awka in an ice box within one hour of collection and analysed within 24 hours of collection. The samples were collected during the dry and wet seasons (January-June, 2016) and were mixed thoroughly before use by inverting the bottles twenty-five times.

\subsection{Fungal Isolation}

The water samples were serially diluted before the analysis. The fungal isolation was carried out using the spread plate technique. Sabouraud dextrose agar (SDA) was used as the growth medium and it was prepared based on the manufacturer's instructions. Chloramphenicol $(0.05 \mathrm{mg} / \mathrm{ml})$ was added to the medium to inhibit bacterial growth. One millilitre of the serially-diluted sample $\left(10^{3}\right)$ was dispensed into the medium and evenly spread over the surface with a sterile glass rod. The plate was covered and incubated at $28^{\circ} \mathrm{C}$ for 72 hours after which the fungal colonies that developed were counted and the result recorded. Each colony was subcultured on sterile SDA plate and later stored on sterile SDA slant for characterization and identification.

\subsection{Characterization and Identification of the Fungal Isolates}

Colony morphology, Cellular morphology, Lactophenol cotton blue staining, Germ tube test, Slide culture, Gram staining, Sugar assimilation, urease, motility and Chlamydospore formation tests were carried out as done by Onuorah et al [9] to characterize the fungi. They were identified according to the description of David et al [10].

\subsubsection{Colony morphology and cellular morphology}

The colony morphology determination was based on the color, elevation, margin and shape while the cellular morphology determination was based on the shape and arrangement of the cells.

\subsubsection{Germ tube test}

$0.5 \mathrm{ml}$ of human serum was dispensed in a test tube. The serum was thereafter inoculated with a yeast colony. The tube was incubated at $37^{\circ} \mathrm{C}$ for three hours. A sterile pasteur pipette was used to transfer a drop of the serum yeast culture to a clean slide, which was thereafter covered with a cover slip and examined under the microscope for the presence of sprouting yeast cells in the form of tube-like outgrowths from the cell.

\subsubsection{Slide culture test}

A portion of the aerial mycelia was inoculated on sterile sabouraud dextrose agar with a sterile inoculating loop. The slide was then incubated at $28^{\circ} \mathrm{C}$ for 24 hours and stained with lactophenol cotton blue dye. It was thereafter covered with a cover slip and examined under the microscope.

\subsubsection{Gram staining}

Gram staining was carried out to determine the gram reaction of the yeast isolates. A smear of the yeast isolate was made on a clean slide and allowed to dry. It was heat-fixed by passing it through the bunsen burner. The smear was flooded with crystal violet solution and left for 60 seconds before washing off with clean water. Lugol's iodine solution was next applied and allowed to stand for 60 seconds before being washed off. The slide was after that decolorized with acetone for 10 seconds and washed off and stained with safranin solution and left for one minute after which it was washed off with water and allowed to dry in air. The slide was then examined under the oil immersion objective of the microscope.

\subsubsection{Sugar assimilation test}

Peptone water broth was prepared based on the manufacturer's instruction. Bromothylmol blue indicator and $1 \%$ of the test sugar were added to the broth which was thereafter dispensed in $5 \mathrm{ml}$ amounts into test tubes. Durham tubes were inserted into the test tubes which were then sterilized in an autoclave at $121^{\circ} \mathrm{C}$ for 15 minutes and upon cooling, the test organism was inoculated into the test tubes. Incubation was carried out at $28^{\circ} \mathrm{C}$ for 24 hours. A change in the colour of the mixture indicated acid production while gas production was indicated by a void in the durham tubes. The sugars used were glucose, sucrose, lactose and mannitol.

\subsubsection{Motility test}

Each yeast isolate was separately inoculated into a semi-solid sabouraud dextrose agar using a sterile straight wire and incubated at $37^{\circ} \mathrm{C}$ for 48 hours. Migration of the isolates away from the line of inoculation was a positive result while lack of migration away from the line of inoculation indicated a negative result. 


\subsubsection{Urease test}

The medium used was Urea broth. Test tubes were sterilized and $2 \mathrm{ml}$ of the broth was dispensed into the test tubes. The test organism was heavily inoculated into the test tubes and incubated at $28^{\circ} \mathrm{C}$ for 48 hours. The development of a pink colour indicated a positive reaction.

\subsubsection{Chlamydospore formation test}

Each yeast isolate was inoculated on corn meal-tween 80 agar and incubated at $28^{\circ} \mathrm{C}$ for 72 hours and introduced on a slide. The isolate was stained with lactophenol cotton blue dye and viewed under the objective lens of the microscope for the presence of chlamydospore.

\subsubsection{Lactophenol cotton blue staining}

A portion of the test fungus was smeared on a slide and a drop of lactophenol cotton blue dye was introduced. The slide was covered with a cover slip avoiding bubbles and viewed under the microscope.

\section{Results}

The average fungal counts of the hand-dug shallow well water samples during the dry and wet seasons are presented in Table 1. The counts were $3.5 \times 10^{3} \mathrm{cfu} / \mathrm{ml}-8.2 \times 10^{3} \mathrm{cfu} / \mathrm{ml}$ during the dry season and $5.1 \times 10^{3} \mathrm{cfu} / \mathrm{ml}-10.6 \times 10^{3} \mathrm{cfu} / \mathrm{ml}$ during the wet season. The well water samples from Umuokpu Awka had the lowest count during both seasons while samples from Umuogbo Awka had the highest count during the dry and wet seasons.

Table 1. Average Fungal Counts of the Hand-Dug Shallow Well Water Samples during the Dry and Wet Seasons

\begin{tabular}{|c|c|c|c|}
\hline Sample & Well location & $\begin{array}{c}\text { Dry season } \\
\left(\times 10^{3} \mathrm{cfu} / \mathrm{ml}\right)\end{array}$ & $\begin{array}{c}\text { Wet season } \\
\left(\mathrm{x} 10^{3} \mathrm{cfu} / \mathrm{ml}\right)\end{array}$ \\
\hline 1 & Okpuno Awka & 5.0 & 7.3 \\
\hline 2 & Ifite Awka & 6.1 & 8.5 \\
\hline 3 & Okperi Awka & 7.0 & 9.9 \\
\hline 4 & Umuogbo Awka & 8.2 & 10.6 \\
\hline 5 & Ogbengwu Awka & 7.4 & 8.7 \\
\hline 6 & Umuokpu Awka & 3.5 & 5.1 \\
\hline 7 & Umunagu Awka & 4.6 & 6.0 \\
\hline 8 & Sugarline Amansea & 4.0 & 5.6 \\
\hline 9 & Ngo Amansea & 4.4 & 5.8 \\
\hline 10 & $\begin{array}{c}\text { Omeluora Close } \\
\text { Amansea }\end{array}$ & 4.7 & 5.2 \\
\hline 11 & Okoye Close Amansea & 5.3 & 6.8 \\
\hline 12 & Orji Avenue Amansea & 6.5 & 8.0 \\
\hline 13 & $\begin{array}{c}\text { Akurulo Avenue } \\
\text { Amansea }\end{array}$ & 3.7 & 5.4 \\
\hline 14 & Obi Avenue Amansea & 4.2 & 5.9 \\
\hline 15 & $\begin{array}{c}\text { Kenneth Close } \\
\text { Amansea }\end{array}$ & 3.9 & 5.5 \\
\hline
\end{tabular}

Table 2 showed the colonial and microscopic characteristics of the moulds isolated from the water samples during the dry and wet seasons. They were identified as Microsporium canis, Penicillium chrysogenum, Alternaria alternata, Mucor mucedo and Sepedonium chrysospermum.

Table 2. Colonial and Microscopic Characteristics of the Moulds Isolated from the Water Samples during the Dry and Wet Seasons

\begin{tabular}{|c|l|l|c|}
\hline Isolate & \multicolumn{1}{|c|}{ Colonial Characteristics } & \multicolumn{1}{|c|}{ Microscopic Characteristics } & Organisms \\
\hline 1 & $\begin{array}{l}\text { Colonies were flat, spreading, and white in } \\
\text { colour with a dense cottony surface and bright } \\
\text { yellow reverse. }\end{array}$ & $\begin{array}{l}\text { Macroconidia were spindle-shaped with 5-15 cells } \\
\text { and were thick-walled }\end{array}$ & Microsporium canis \\
\hline 2 & $\begin{array}{l}\text { Colonies were rapidly growing, with velvety } \\
\text { texture. The colour was light green on the } \\
\text { surface. }\end{array}$ & $\begin{array}{l}\text { Conidia were greenish and globose. Hyphae were } \\
\text { septate and branched. Conidiophores were simple, } \\
\text { long and erect. Spore heads were brush-like, and } \\
\text { bore long chains of conidia. }\end{array}$ & Penicillium chrysogenum \\
\hline 3 & $\begin{array}{l}\text { Colonies were rapidly growing, with wooly } \\
\text { texture. The colour was olive brown on the } \\
\text { surface }\end{array}$ & $\begin{array}{l}\text { Conidiophores were brown, septate and simple. } \\
\text { Hyphae were septate }\end{array}$ & Alternaria alternata \\
\hline 4 & $\begin{array}{l}\text { Colonies were rapidly growing, with wooly } \\
\text { texture. The colour was grey on the surface }\end{array}$ & $\begin{array}{l}\text { Hyphae were broad and not septate. } \\
\text { Sporangiophores were branched while the } \\
\text { Sporangiospores were ellipsoidal. Rhizoids and } \\
\text { stolons were absent. }\end{array}$ & Mucor mucedo \\
\hline 5 & $\begin{array}{l}\text { Colonies were rapidly growing, with wooly } \\
\text { texture. The colour was golden yellow on the } \\
\text { surface }\end{array}$ & $\begin{array}{l}\text { Hyphae were septate. The conidia were } \\
\text { unicellular, terminal, solitary and thick-walled. } \\
\text { Conidiophores were a bit differentiated from the } \\
\text { vegetable hyphae. }\end{array}$ & $\begin{array}{c}\text { Sepedonium } \\
\text { chrysospermum }\end{array}$ \\
\hline
\end{tabular}


Table 3. Morphological and biochemical Characteristics of the Yeasts from the Water Samples during the Dry and Wet Seasons.

\begin{tabular}{|c|c|c|c|c|c|c|c|c|c|c|}
\hline Isolate & Colour & Shape & $\begin{array}{c}\text { Urease } \\
\text { test }\end{array}$ & $\begin{array}{c}\text { Germ } \\
\text { tube } \\
\text { test }\end{array}$ & $\begin{array}{c}\text { Glucose } \\
\text { assimilation }\end{array}$ & $\begin{array}{c}\text { Lactose } \\
\text { assimilation }\end{array}$ & $\begin{array}{c}\text { Sucrose } \\
\text { assimilation }\end{array}$ & $\begin{array}{c}\text { Mannitol } \\
\text { assimilation }\end{array}$ & Motility & Organisms \\
\hline 1 & Cream & Round & - & + & + & - & - & + & - & $\begin{array}{l}\text { Candida } \\
\text { albicans }\end{array}$ \\
\hline 2 & Cream & Round & + & - & - & - & - & + & - & $\begin{array}{c}\text { Cryptococcus } \\
\text { neoformans }\end{array}$ \\
\hline 3 & $\begin{array}{c}\text { Coral } \\
\text { red }\end{array}$ & Round & + & - & - & - & - & + & - & $\begin{array}{c}\text { Rhodotorula } \\
\text { harrison }\end{array}$ \\
\hline
\end{tabular}

$+=$ Positive reaction

$=$ Negative reaction

In Table 3 is shown the morphological and biochemical characteristics of the yeasts isolated from the water samples during the dry and wet seasons. The yeasts were Candida albicans, Cryptococcus neoformans and Rhodotorula harrison.

The number of the hand-dug shallow water wells with the fungal isolates during the dry and wet season is presented in Table $4.46 .7 \%, 6.7 \%, 20.0 \%, 26.7 \%$ and $6.7 \%$ of the water wells contained Candida albicans, Cryptococcus neoformans, Rhodotorula harrison, Penicillium chrysogenum and Mucor mucedo respectively during the dry season while $60.0 \%, 20.0 \%, 26.7 \%, 6.7 \%, 40.0 \%, 13.3 \%$, $20.0 \%$ and $6.7 \%$ of the water wells contained Candida albicans, Cryptococcus neoformans, Rhodotorula harrison, Microsporium canis, Penicillium chrysogenum, Alternaria alternata, Mucor mucedo and Sepedonium chrysospermum respectively during the wet season.

Table 4. Number of the Hand-dug Shallow Water Wells with the Fungal Isolates during the Dry and Wet Seasons

\begin{tabular}{|c|c|c|}
\hline Fungal Isolate & Dry Season (\%) & Wet Season (\%) \\
\hline Candida albicans & 46.7 & 60.0 \\
\hline $\begin{array}{c}\text { Cryptococcus } \\
\text { neoformans }\end{array}$ & 6.7 & 20.0 \\
\hline Rhodotorula harrison & 20.0 & 26.7 \\
\hline Microsporium canis & Not detected & 6.7 \\
\hline Penicillium chrysogenum & 26.7 & 40.0 \\
\hline Alternaria alternata & Not detected & 13.3 \\
\hline Mucor mucedo & 6.7 & 20.0 \\
\hline $\begin{array}{c}\text { Sepedonium } \\
\text { chrysospermum }\end{array}$ & Not detected & 6.7 \\
\hline
\end{tabular}

The frequency of isolation of the fungal isolates in the hand-dug shallow well water samples during the dry and wet seasons is presented in Table 5. The frequency of isolation during the dry season was $42.0 \%, 9.6 \%, 11.5 \%, 28.0 \%$ and $8.9 \%$ for Candida albicans, Cryptococcus neoformans, Rhodororula harrison, Penicillium chrysogenum and Mucor mucedo respectively while the frequency of isolation of the isolates during the wet season was $44 . .8 \%, 10.2 \%, 12.6 \%$, $0.2 \%, 29.3 \%, 0.3 \%, 9.2 \%$ and $0.2 \%$ for Candida albicans, Cryptococcus neoformans, Rhodotorula harrison, Microsporium canis, Penicillium chrysogenum, Alternaria alternata, Mucor mucedo and Sepedonium chrysospermum respectively. Candida albicans was most frequently isolated during both seasons with an average frequency of $43.4 \%$ while Microsporium canis and Sepedonium chrysospermum had the lowest frequency of isolation during both seasons, with an average frequency of $0.1 \%$ each.

Table 5. Frequency of Isolation of the Fungal Isolates in the Hand-Dug Shallow Well Water Samples during the Dry and Wet Seasons.

\begin{tabular}{|c|c|c|c|}
\hline Fungal Isolate & $\begin{array}{c}\text { Dry Season } \\
(\mathbf{\%})\end{array}$ & $\begin{array}{c}\text { Wet Season } \\
(\mathbf{\%})\end{array}$ & Average \% \\
\hline Candida albicans & 42.0 & 44.8 & 43.4 \\
\hline $\begin{array}{c}\text { Cryptococcus } \\
\text { neoformans }\end{array}$ & 9.6 & 10.2 & 9.9 \\
\hline Rhodotorula harrison & 11.5 & 12.6 & 12.1 \\
\hline Microsporium canis & Not detected & 0.2 & 0.1 \\
\hline $\begin{array}{c}\text { Penicillium } \\
\text { chrysogenum }\end{array}$ & 28.0 & 29.3 & 28.7 \\
\hline Alternaria alternata & Not detected & 0.3 & 0.2 \\
\hline Mucor mucedo & 8.9 & 9.2 & 9.1 \\
\hline $\begin{array}{c}\text { Sepedonium } \\
\text { chrysospermum }\end{array}$ & Not detected & 0.2 & 0.1 \\
\hline
\end{tabular}

\section{Discussion}

The result of the analysis of the samples from the hand-dug shallow water wells during the dry and wet seasons showed that they were contaminated with fungi (Table 1). The moulds isolated from the samples during both seasons were Microsporium canis, Penicillium chrysogenum, Alternaria alternata, Mucor mucedo and Sepedonium chrysospermum. (Table 2) while the yeasts were Candida albicans, Cryptococcus neoformans and Rhodotorula harrison (Table 3).

More fungi were isolated during the wet than the dry season. The rainfall during the wet season as well as the possible accumulation of nutrients in the water wells may have been responsible for the increased number of fungi during the season. The nutrients must have been carried by flood and deposited near the water wells eventually resulting in their seepage into the ground water.

Candida albicans occurred in $46.7 \%$ and $60.0 \%$ of the water wells during the dry and wet seasons; Cryptococcus neoformans, $6.7 \%$ and $20.0 \%$; Rhodotorula harrison, $20.0 \%$ and 26.7\%; Penicillium chrysogenum, $26.7 \%$ and $40.0 \%$ while Mucor mucedo occurred in $6.7 \%$ and $20.0 \%$ of the wells during both seasons. Microsporium canis, Alternaria 
alternata and Sepedonium chrysospermum occurred in $6.7 \%$, $13,3 \%$ and $6.7 \%$ of the shallow water wells during the wet season only (Table 4). The result showed that more of the water wells had fungi during the wet than the dry season. This may be attributed to the seepage of water containing microorganisms into the wells.

The average frequency of isolation of the fungal isolates in the hand-dug shallow well water samples for both seasons was $43.4 \%, 9.9 \%, 12.1 \%, 0.1 \%, 28.7 \%, 0.2 \%, 9.1 \%$ and $0.1 \%$ respectively for Candida albicans, Cryptococcus neoformans, Rhodotorula harrison, Microsporium canis, Penicillium chrysogenum, Alternaria alternata, Mucor mucedo and Sepedonium chrysospermum (Table 5).

Candida albicans is a dimorphic fungus and one of the genera that cause candidiasis in humans [11,12] and is responsible for $50-90 \%$ of all cases of candidiasis of humans. It is a flora of the human gastrointestinal tract and is detectable in the gastrointestinal tract in $40 \%$ of healthy adults [13]. It's presence in the water samples may be because most of the wells sampled were located beside septic tanks and as such, effluents from such tanks must have seeped into them.

Cryptococcus neoformans is a yeast that can live in both plants and animals [14] and is often found in bird excrement and soil contaminated by bird excrement which contains high amount of nitrogen containing compounds. The yeast causes Cryptococcosis and most infections occur in the lungs [15]. It also causes fungal meningitis and encephalitis especially as a secondary infection for AIDS patients thereby making it a particularly dangerous fungus. The pollution of these waters by the fungus may have come from the droppings of chicken and pigeons that were roaming within the vicinity of the water wells.

Rhodotorula harrison is a pink basidiomycota yeast that is commonly found in the air, freshwater and sea water [16]. It is an emerging opportunistic yeast pathogen, particularly in immuno-compromised patients. This yeast has a strong affinity for plastics and may have contaminated this well water through the different plastic drawers used by different individuals to fetch water from the wells.

Microsporium canis is a pathogenic dermatophyte that infects the upper dead layers of the skin of domesticated cats and occasionally dogs and humans [17]. It has been identified as a casual agent of ringworm infections in pets, tinea capitis and tinea corporis in humans particularly in children [18]. Dogs were seen roaming around some of the premises where the shallow wells were located. The droppings from such dogs may have infiltrated into the groundwater leading to the presence of Microsporium canis in the water samples.

Penicillium chrysogenum is a common fungus that inhabits a wide range of habitats including moist soils with plentiful quantities of carbon and nitrogen for mycorrhizal growth [19]. It plays a role in the medical community as either a pathogen [20] or allergen [21] and is a cause of infection in people with severely suppressed immune systems. Symptoms of the infections caused by this fungus include Pneumonia, localized granulomas, fungus balls and systemic infections. The fungus is one of the most frequent organisms found in water. It may have entered the water through the soil and air. It's implication in allergy, asthma and other respiratory problems have been reported [22].

Alternaria alternata is found in habitats such as the soil, corn silage, rotten wood, compost, bird nests and various forest plants. It is an opportunistic human pathogen and can cause upper respiratory tract infections and asthma in humans with compromised immunity [23]. In immuno-competent individuals, the organism can colonize the prenasal sinuses leading to the development of invasive diseases. This organism must have percolated through the soil and polluted the shallow water wells.

Mucor mucedo is found in soil, dungs, water, nose effluent of cows, composted leaf litter, grapes, tomatoes and stored wheat. It is a fungal plant and human pathogen which affects the respiratory system. Exposure to high levels of the fungus can cause symptoms of asthma, elevated temperature, flu-like symptoms, malaise and difficulty in breathing and can be extremely dangerous to individuals with suppressed immune systems [24]. This fungus may have found its way into the water wells.

Sepedonium chrysospermum is a common soil fungus and parasite of fleshy fungi. It rarely causes infections in humans but Yogo et al [25] reported an intra-abdominal infection in an immune-suppressed patient. The fungus may have entered the water samples through the soil.

Latrines or sewers should not be located within $100 \mathrm{~m}$ of the wells and animal breeding must not be done within $50 \mathrm{~m}$ of such wells. The wells must be properly capped and without cracks. In addition, the sanitary condition of their surroundings must be adequate. These measures would reduce the incidence of fungi in the water wells and the health risk they pose to humans.

\section{Conclusions}

The hand-dug shallow water wells examined in Awka metropolis during the dry and wet seasons were polluted with fungal pathogens. This pollution may pose a serious threat to public health and safety. Periodic analysis of all the shallow water wells in the metropolis for the presence of fungi is therefore imperative. The water from the wells must be adequately treated before use by humans. Sand filtration, ozonation and chlorination are recommended.

\section{REFERENCES}

[1] C.L. Zeman, B. Kross, M. Vlad. A nested case-control study of methanoglobinaemia, risk factor in children of Transylvania, Romania. Environmental Health Prospectives. Vol. 110, No.8, 817-822, 2002. DOI:10.1289/ehp/02110817. 
[2] E.A. Gay, B.N. Proop. Aspects of River Pollution. Butterworths scientific Publication, London, Pp.261-270, 1993.

[3] B.S. Badmus, A.A. Odewande, E.A. Ayolabi, T. Ayodele. Experimental investigation of leachate contamination on ground water exploration in basement complex area. Journal of Natural Sciences, Engineering and Technology, Vol. 8, No.1, 11-15, 2009.

[4] National Water Supply and Sanitation Policy. Federal Ministry of Water Resources, Lagos, Nigeria, Pp.35, 2000.

[5] World Health Organization. Algae and Cyanobacteria in fresh water. In Guideline for safe recreational water environments, World Health Organization Press, Geneva, Switzerland, Pp.136-138, 2003.

[6] World Health Organization. Guideline for drinking water quality, $3^{\text {rd }}$ edition, WHO Press Geneva, Switzerland, Pp.398, 2006.

[7] P.M. Kirk, P.F. Cannon, J.C. David, J.A. Stalpers. Ainsworth and Bisby's dictionary of the fungi, $9^{\text {th }}$ edition, CAB International University Press Cambridge, United Kingdom, 2001.

[8] D. Cabral, E. Virginia, P. Fernandez. Fungal spoilage of bottled mineral water. International Journal of Food Microbiology. Vol. 72, No.1-2, 73-76, 2002. http://dx.doi.or $\mathrm{g} / 10.1016 / \mathrm{S} 0168-1605$ (01) 00628-6.

[9] S. Onuorah, I. Obika, M. Orji, F. Odibo. Microbial contaminants in the commercial aviation fuel obtained from Benin City Airport, Nigeria. Universal Journal of Microbiology Research, Vol. 3, No.3, 31-35, 2015. DOI:10.13189/ujmr.2015.030301.

[10] E. David, D. Stephen, A. Helen, H. Rosemary, B. Robyn. Descriptions of medical fungi. Mycology Unit Women's and children hospital, School of molecular and biomedical Science, University of Adelaide, $2^{\text {nd }}$ edition. Pp 58, 2007.

[11] A. Erdogan, S.S. Rao. Small intestinal fungal overgrowth. Current Gastroenterology Reports, Vol. 17, No.4, 16, 2015. doi:10.1007/S11894-015-0436-2.

[12] N. Martins, I.C. Ferreira, L. Barros, S. Silva, M. Henriques. Candidiasis: Predisposing factors, prevention, diagnosis and alternative treatment. Mycopathologia, Vol. 177, No.5-6, 223-240, 2014. doi: 10.1007/S11046-014-9749-1

[13] P.K. Mukherjee, B. Sendid, G. Hoarau, J.F. Colombel, D. Poulain, M.A. Ghannoum. Mycobiota in gastrointestinal diseases. Nature Reviews. Gastroenterology and Hepatology. Vol. 12, No.2, 77-87, 2015. doi:10.1038/nrgastro.2014.188.

[14] S.S. Ingavale, Y.C. Chang, H. Lee, C.M. McClelland, M.L. Leong, K.J. Kwon-Chung. Importance of mitochondria in survival of Cryptococcus neoformans under low oxygen conditions and tolerance to cobalt chloride. PLoS Pathogens, Vol. 4, No.9, e1000115, 2008. DOI:10.1371/journal.ppat.10
00155.

[15] K. Tripathi. V. Mor, N.K. Bairwa, M. Del Poeta, B.K. Mohanty. Hydroxyurea treatment inhibits proliferation of Cryptococcus neoformans in mice. Frontiers in Microbiology, Vol. 3, 187, 2012. doi:10.3389/fmicb.2012.00187

[16] D. Libkind, M. Moline, R. Sommanuga, J.P. Sampaio, M. Van Broock. Phylogenic distribution of fungal mycosporines within the Pucciniomycotina (Basidiomycota). Yeast, Vol. 28, No.8, 619-627, 2011. DOI:10.1002/yea.1891.

[17] S. Shafiee, A.R. Khosravi, I.A. Tamai. Comparative study of Microsporium canis isolates by DNA fingerprinting. Mycoses, Vol. 57, No. 8, 507-512, 2014. doi:10.1111/myc.12189.

[18] G. Ginter-Hanselmayer, J. Smolle, A. Gupta. Itraconazole in the treatment of tinea capitis caused by Microsporium canis: experience in a large cohort. Pediatric Dermatology, Vol. 21, No.4, 499-502, 2004.doi:10.1111/j.0736-8046.2004.21419.x.

[19] D.K. Jha, G.D. Sharma, R.A. Mishra. Ecology of soil microflora and mycorrhizal symbionts in degraded forests at two altitudes. Biology and fertility of soils, Vol. 12, No.4, 272-278, 1992. DOI: 10.1007/BF00336043.

[20] A.L. Barcus, S.D. Burdette, T.E. Herchline. Intestinal invasion and disseminated disease associated with Penicillium chrysogenum. Annals of Clinical Microbiology and Antimicrobials, Vol. 4, 21, 2005. DOI: 10.1186/1476-0711-4 -21 .

[21] H.D. Shen, H. Chou, M.F. Tam, C.Y. Chang, H.Y. Lai, S.R. Wang. Molecular and immunological characterization of Pench 18, the vacuolar serine protease major allergen of Penicillium chrysogenum European Journal of Allergy and Clinical Immunology, Vol. 58, No.10, 993-1002, 2003. DOI:10.1034/j.1398-9995.2003.00107.x

[22] D.W. Denning, B.R. O’ Driscoll, C.M. Hogaboam, P. Bowyer, R.N. Niven. The link between fungi and severe asthma: a summary of the evidence. The European Respiratory Journal, Vol. 27, No. 3, 615-626, 2006. DOI:10.1183/09031936.06.0 0074705 .

[23] P.M. Wiest, K. Wiese, M.R. Jacobs, A.B. Morrissey, T.I. Abelson, W. Witt, M.M. Lederman. Alternaria infection in a patient with acquired immunodeficiency syndrome: Case Report and Review of Invasive Alternaria infections. Reviews of Infectious Diseases, Vol. 9, No.4, 799-803, 1987. doi:10.1093/clinids/9.4.799.

[24] M.A.A. Schipper, J.A. Stalpers. Zygomycetes: The Order Mucorales. In Howard, D.H. (ed.), Pathogenic fungi in Humans and Animals. $2^{\text {nd }}$ Edition, Marcel Dekker Incorporated, New York, Pp 67-125, 2003.

[25] N. Yogo, L. Shapiro, K.M. Erlandson. Sepedonium intra-abdominal infection: a case report and review of an emerging fungal infection. The Journal of Antimicrobial Chemotheraphy, Vol. 69, No.9, 2583-2585, 2014. doi:10.1093/jac/dku138. 